\title{
Ursula King
}

Spirit of Fire: The Life and Vision of Pierre Teilhard de Chardin. Revised Edition.

Maryknoll: Ny: Orbis Books, 2015. Pp. xiv + 258. Pb, \$26.

In the epilogue to this volume, Ursula King summarizes the broad current interest in Teilhard. Presciently, she highlights one aspect of Teilhard's thought that is suddenly at the center of the controversy surrounding Pope Francis's Laudato si'. She notes that some thinkers are taking up Teilhard's idea of the fundamental relationship between the biosphere and the human sphere, which Teilhard famously called the noosphere. That term implied more than just a sociological description of human society. It suggested that all of human life is linked in its progression towards greater understanding and self-consciousness. We are organically part of the noosphere and thus joined to one another and to the biosphere. From that starting point, it is possible to build an ethics of responsibility for all of creation.

This is what Francis does, especially in Chapter Two, "The Gospel of Creation," where he invites a dialogue between religion and science. Francis presents "the rich contribution which religions can make towards an integral ecology and the full development of humanity" (Francis I, Laudato si', \62). This integral ecology has both a physical and moral dimension. We are part of the earth and as such bound to the future of our planet. We are responsible for other creatures. Our care for the earth is a function of our moral responsibility. We also share a common destiny. "The ultimate destiny of the universe is in the fullness of God, which has already been attained by the risen Christ, the measure of the maturity of all things"( $\left(\mathbf{8 3}_{3}\right)$. At this point, the pope cites Teilhard.

With this revival of interest in Teilhard, Orbis has decided to issue a new edition of a book originally published in 1996 with the same title. The entire Epilogue is new, as is the excellent bibliography, which is up to date. It is a bit harder to tell exactly what else is new, but fortunately King's original work stands up well to the passage of twenty years. This work remains a revealing study of one of the three most important Jesuit theologians of the last century; the other two, Karl Rahner and Bernard Lonergan, have not yet seen a renaissance. King is thoroughly familiar with the entire corpus of Teilhard's works, in their published and manuscript forms. She traces with great care the development of his thought over his entire life from his early days in Auvergne, to his paleontological explorations in Egypt and Mongolia, to China and the discovery of Peking Man, and to the last moment of what she rightly calls his "American exile" (217) on Easter Sunday 1955 in New York. She brings out the human side of Teilhard as well, even including a chapter on his dear friend Lucile Swan — apt, given King's focus on his inner life. 
Particularly striking is the way she highlights Teilhard's experience of suffering. At a young age he saw his parents and siblings cut down by disease and war. When he entered the Society of Jesus, they were being persecuted by the French government. He had to go to Hastings in the south of England to study theology because the government was closing religious institutions. Three years after being ordained in 1911, he was inducted into the French army. He served for four years on the front lines in the trenches as a stretcher bearer, surrounded by death and destruction. When he turned to science, it was the dead, not the living that he studied. Somehow, he saw in all that darkness a purpose, a spirit of fire, moving everything toward a glorious end.

King's work is not a biography. While she does trace the outlines of Teilhard's life, those lines are thin, pencil marks that do little to color in the historical background. She is just not interested in painting a finely shaded picture of the theological life in France in the first half of the twentieth century, or the struggles with the laic French state, for instance. We do learn a little about the broader historical forces that transformed Teilhard's society, especially the First World War, but we are shown those things only through the prism of Teilhard's own ideas, often his most inward musings about his own life and relationship with God. Those delicate images of a soul seeking to define its place in God's creation are not easily drawn on a canvass too detailed-as every age is - with bold contradictions and counter-forces. The author is only interested in Teilhard's thought, but the irony of such an approach is that the significance of that thought may be diminished. Such a close focus on the sage's vision inevitably results in a work that some would see as panegyric.

Yet with Teilhard, such an approach does much less harm than it would in the life of a contemporary of his, such as Charles de Gaulle. Teilhard was primarily a visionary, not a church leader, nor a statesman. His inner life is his legacy. His was a new vision that linked the great Christian contemplative tradition with the evolutionary life of the universe in all its fury and fire. King understands that superbly. In her pages, we hear Teilhard, we see what he saw. She never insists on standing between us, never intrudes with some pretentious theory, never calls attention to her presence. Teilhard's thought does not require any one pulling it into the twenty-first century to make it relevant. We are all still running to catch up, trying to comprehend just what that extraordinary man saw. And there is no better guide along that path than Ursula King.

\section{John Farina \\ George Mason University \\ jfarina@gmu.edu}

DOI $10.1163 / 22141332-00301005-31$ 